\title{
The prevalence of underweight, overweight and obesity in a multiracial group of urban adolescent schoolchildren in the Cape Metropole area of Cape Town
}

\author{
Van Niekerk S-M, ${ }^{1}$ PhD, Post-Doctoral Fellow; Grimmer K, ${ }^{1,2}$ PhD, Professor Extraordinaire; Louw Q, ${ }^{\text {PhD }}$, Professor \\ ${ }^{1}$ Physiotherapy Division, Faculty of Medicine and Health Sciences, Stellenbosch University \\ ${ }^{2}$ International Centre for Allied Health Evidence (ICAHE) \\ Correspondence to: Sjan-Mari van Niekerk, e-mail: smvanniekerk@sun.ac.za \\ Keywords: BMI, adolescents, prevalence, underweight, overweight, obese
}

\section{Abstract}

Objective: The objective was to determine the prevalence of underweight, overweight and obesity in high school learners in the Cape Town area.

Design: A cross-sectional study was conducted.

Setting: High schools in the Cape Metropole Area of the Western Cape.

Subjects: A complex cluster sampling procedure was followed. Thirty-six students per school were selected from each randomly selected school. Thirteen- to 18-year-old pupils were eligible for inclusion.

Outcome measures: Height and weight measurements.

Results: The sample comprised 689 students. There were considerably more underweight adolescent boys than adolescent girls $(17.3 \%$ boys to $9.9 \%$ girls), and double the frequency of overweight adolescent girls than adolescent boys ( $7.7 \%$ girls to $3.5 \%$ boys). The 14 -year-old boys had the highest prevalence of underweight (55.2\%), and the 17-year-old girls the highest prevalence of overweight (22\%). The highest prevalence of obesity was found in 15-year-old boys (11.1\%), who also demonstrated a relatively high prevalence of underweight (30.2\%).

Conclusion: This study reported on a substantial percentage of underweight adolescents (27.1\%). Noteworthy levels of overweight and obesity in adolescent girls added to the substantial prevalence of underweight in adolescent boys. Africa has enough to contend with in respect of transmissible diseases, without additional lifestyle-based health burdens.

(P) Peer reviewed. (Submitted: 2013-06-05. Accepted: 2013-10-26.) ๑ SAJCN

S Afr J Clin Nutr 2014;27(1):18-24

\section{Introduction}

Unhealthy weight is a worldwide public health concern affecting adults and children. ${ }^{1}$ Internationally, secular trends of body mass index (BMI) in children in developed countries suggest that the average weight of children is increasing, and the percentage of children who are overweight or obese is also growing. ${ }^{2-7}$ The prevalence of underweight children has remained steady in many developing countries, while that of overweight is increasing, which means that there is a double burden on children's health in many cultures (underweight and overweight). ${ }^{8-11}$ Obesity and malnutrition represent extremes on the spectrum of adiposity, and both are routinely quantified in terms of weight and height relative to the child's age. ${ }^{3}$ Children who are under- or overweight for height are significantly more likely than normal weight-for-height children to suffer preventable diseases in adolescence and adulthood. ${ }^{12}$
Together, undernutrition-related diseases, infectious diseases and obesity-related diseases contribute substantially to the burden of disease in low- and middle-income countries. ${ }^{5}$ Impaired cognitive development and poorer educational achievement are the adverse effects of undernutrition in childhood, ${ }^{13}$ and can result in a high risk of obesity in adulthood. ${ }^{6,14}$

On the other hand, adolescent obesity is associated with serious health problems in adolescence and later adulthood, including a heightened risk of psychosocial morbidity, cardiovascular complications, type 1 and type 2 diabetes, morbidity, premature death and impaired social integration. ${ }^{15-17}$ Thus, an international increase in the prevalence in overweight children in affluent societies will potentially result in increased health costs in the next decade. For this reason, international trends in childhood weight should be closely monitored, and early action taken to slow trends of overweight and obesity. However, there are barriers to monitoring these trends as a variety of definitions are in use. ${ }^{12,18-22}$ 
Table I: Prevalence of underweight, overweight and obesity in school learners according to age in various international countries

\begin{tabular}{|c|c|c|c|c|c|c|}
\hline \multirow[t]{2}{*}{ Author } & \multirow[t]{2}{*}{ Country } & \multicolumn{5}{|c|}{ Prevalence } \\
\hline & & Sample size (n) & $\begin{array}{l}\text { Age group } \\
\text { (years) }\end{array}$ & $\begin{array}{l}\text { Underweight } \\
\qquad(\%)\end{array}$ & Overweight (\%) & Obese (\%) \\
\hline \multirow[t]{7}{*}{ Lissau et al ${ }^{27}$} & USA & 2068 & 13 and 15 & - & $25.5-31$ & $10.8-15.5$ \\
\hline & Ireland & 826 & 13 and 15 & - & $14.2-24.7$ & $2.8-7$ \\
\hline & $\begin{array}{l}\text { Southern portion of western Europe (Greece } \\
\text { and Portugal) }\end{array}$ & 3761 & 13 and 15 & - & $12.5-28.9$ & $3.5-10.8$ \\
\hline & $\begin{array}{l}\text { Nordic countries (Denmark, Finland and } \\
\text { Sweden) }\end{array}$ & 6303 & 13 and 15 & - & $9.8-22.6$ & $1.8-6.9$ \\
\hline & $\begin{array}{l}\text { Central portion of Western Europe (France, } \\
\text { Germany and Belgium) }\end{array}$ & 7402 & 13 and 15 & - & $9.8-15.4$ & $2.7-5.8$ \\
\hline & $\begin{array}{l}\text { Eastern European countries (Czech Republic, } \\
\text { Austria, Lithuania and Slovakia) }\end{array}$ & 7891 & 13 and 15 & - & $8.1-16.5$ & $1.1-6.1$ \\
\hline & Israel & 991 & 13 and 15 & - & $12.3-20.1$ & $3.5-10.8$ \\
\hline Önera et al ${ }^{26}$ & Turkey & 989 & $12-17$ & $12.8 \%$ & 11 & 1 \\
\hline \multirow[t]{8}{*}{ Janssen et $\mathrm{al}^{28}$} & $\begin{array}{l}\text { North American countries (Canada and the } \\
\text { USA) }\end{array}$ & 7990 & $10-16$ & - & $15.2-18.3$ & $4.1-6.8$ \\
\hline & Great Britain (England, Scotland and Wales) & 8904 & $10-16$ & - & $13.1-16.7$ & $3.0-5.7$ \\
\hline & $\begin{array}{l}\text { Southern portion of western Europe (Greece, } \\
\text { Italy, Malta, Portugal and Spain) }\end{array}$ & 14298 & $10-16$ & - & $14.8-16.3$ & $2.2-7.9$ \\
\hline & $\begin{array}{l}\text { Nordic countries (Denmark, Finland, Norway } \\
\text { and Sweden) }\end{array}$ & 17136 & $10-16$ & - & $9.8-11.8$ & $1.3-2.5$ \\
\hline & $\begin{array}{l}\text { Central portion of western Europe (Austria, } \\
\text { Belgium, France, Germany, Netherlands and } \\
\text { Switzerland) }\end{array}$ & 33488 & $10-16$ & - & $7-10.9$ & $0.8-1.9$ \\
\hline & $\begin{array}{l}\text { South-west corner of eastern Europe (Croatia, } \\
\text { Hungary, Macedonia and Slovenia) }\end{array}$ & 15355 & $10-16$ & - & $10.5-12.9$ & $1.8-2.4$ \\
\hline & $\begin{array}{l}\text { Eastern European countries (Czech Republic, } \\
\text { Estonia, Latvia, Lithuania, Poland, Russia and } \\
\text { the Ukraine) }\end{array}$ & 33031 & $10-16$ & - & $5.3-9.1$ & $0.4-1.1$ \\
\hline & Israel & 4200 & $10-16$ & - & 9.3 & 1.8 \\
\hline \multirow{3}{*}{$\begin{array}{l}\text { Wang, Monteiro, } \\
\text { Popkin }^{29}\end{array}$} & USA & 6110 & $10-18$ & - & 15.2 & 10.7 \\
\hline & Russia & 6883 & $10-18$ & - & 7.4 & 3.2 \\
\hline & China & 3028 & $10-18$ & - & 3 & 1.8 \\
\hline
\end{tabular}

Anthropometry reporting weight-for-height measures is a common approach that is used to identify people at risk of nutritional disorders. ${ }^{23} \mathrm{BMI}$ is another measure. This was developed by Lambert Quetelet, a Flemish mathematician, in the $19^{\text {th }}$ century, ${ }^{24}$ calculated with the formula of weight (in $\mathrm{kg}$ ) divided by height (in metres) squared. The classification of malnutrition (underweight) in later childhood and adolescents has been hampered because of lack of agreement on an appropriate threshold for international use..$^{25}$ Underweight has been classified according to various methods. ${ }^{12,18-22}$ However, only recently Cole $^{2}$ proposed internationally comparable cut-off points to define underweight in children and adolescents.

We have summarised the international literature, published since 2000, with respect to underweight, overweight and obesity (Table I).There is a dearth of information in the literature on the prevalence of underweight in adolescents. Only Önera et $\mathrm{al}^{28}$ report on this topic. It is apparent that the USA has the highest prevalence of overweight and obesity, with more than double the percentage of adolescents considered to be obese than any other country. ${ }^{26}$ Of the European countries and Israel, the highest prevalence of overweight was found in Greece and Portugal, and the lowest in Lithuania. ${ }^{26}$ Janssen et $\mathrm{al}^{27}$ described two trends in their findings. The first was that generally, lower levels of overweight were found in children in Central and Eastern Europe countries, whose economies suffered varying degrees of recession in a period of economic and political transition in the 1990s. The second trend was a higher prevalence of overweight in the southern countries of Europe, especially those outside of the former Eastern Bloc. The non-Eastern bloc countries surrounding the Mediterranean showed prevalence rates ranging from $20-40 \%$ for overweight children, while those in northern areas reflected rates of $10-20 \%$. 
Table II: Prevalence of underweight, overweight and obesity

\begin{tabular}{|c|c|c|c|c|c|c|}
\hline \multirow{2}{*}{ Author } & \multirow{2}{*}{ Country } & \multicolumn{5}{|c|}{ Prevalence } \\
\hline & & Sample size (n) & Age group (years) & Underweight (\%) & Overweight (\%) & Obese (\%) \\
\hline Amstrong et al ${ }^{30}$ & $\begin{array}{l}\text { South Africa } \\
\text { (national) }\end{array}$ & 10165 & $6-13$ & - & $7.9-14.3$ & $2.5-6$ \\
\hline $\begin{array}{l}\text { Department of } \\
\text { Health }{ }^{31}\end{array}$ & $\begin{array}{l}\text { South Africa } \\
\text { (national) }\end{array}$ & 2377 & $15-24$ & - & $9.7-19.7$ & $1.8-11$ \\
\hline Jinabhai et al ${ }^{32}$ & $\begin{array}{l}\text { South Africa } \\
\text { (Western Cape) }\end{array}$ & 1272 & $13-17$ & $2.6-18.4$ & $4.2-20.8$ & $0.9-4.2$ \\
\hline $\begin{array}{l}\text { Kimani-Murage } \\
\text { et al }^{33}\end{array}$ & $\begin{array}{l}\text { South Africa (Elgin } \\
\text { Court region) }\end{array}$ & 904 & $15-20$ & 8 & 8 & 4 \\
\hline Kruger $^{34}$ & $\begin{array}{l}\text { South Africa } \\
\text { (Potchefstroom) }\end{array}$ & 1257 & $10-15$ & - & 6.3 & 1.6 \\
\hline Makgae et a $\left.\right|^{35}$ & South Africa (Elisras) & 1802 & $6-13$ & - & $0-4.6$ & - \\
\hline $\begin{array}{l}\text { Monyeki, Kemper, } \\
\text { Makgae }^{15}\end{array}$ & South Africa (Elisras) & 1817 & $7-13$ & - & $0-4.6$ & - \\
\hline Matsha et al ${ }^{36}$ & $\begin{array}{l}\text { South Africa } \\
\text { (Western Cape) }\end{array}$ & 1272 & $10-16$ & - & 15.7 & 30.8 \\
\hline Naude et $\mathrm{al}^{37}$ & $\begin{array}{l}\text { South Africa } \\
\text { (Potchefstroom) }\end{array}$ & 280 & $13-18$ & - & $8.8-12.1$ & 3.4 \\
\hline Reddy et al ${ }^{38}$ & $\begin{array}{l}\text { South Africa } \\
\text { (national) }\end{array}$ & 9224 & $13-19$ & 9 & 16.9 & 4 \\
\hline
\end{tabular}

Table II illustrates the prevalence of underweight, overweight and obesity in South African studies published since 2000. A large difference in the prevalence of underweight and overweight between regions in South Africa is

apparent from these data. Table II includes studies that reported on underweight, overweight and obesity, irrespective of age or gender.

Despite the fact that South Africa is a middle-income country in general, food insecurity remains a problem. Approximately $35 \%$ of households are considered to be food insecure. ${ }^{9}$ This means that these households do not have the means to secure a steady or regular supply of food. Food variety and dietary diversity, associated with the nutritional status of South Africans, is limited in poor communities in South Africa, ${ }^{37-39}$ such as the Cape Metropole in the Western Cape province.

Subsistence agriculture in the Cape Metropole area is hindered by small plot sizes and a high number of families living in apartment blocks in which growing vegetable gardens is not possible. People have to predominantly rely on purchased food in an area in which they have low purchasing power. This can result in food insecurity and consequent malnutrition.

National electrification in South Africa in the few years postapartheid (as well as improvements in many families' income) has potentially contributed to a general increase in the availability of televisions at home. This may have led to decreased physical activity in Western Cape adolescents..$^{24,37}$ Decreased physical activity is also associated with the increased consumption of unhealthy foods that are promoted in television advertisements. ${ }^{40}$
This paper reports on the recently estimated prevalence of underweight, overweight and obesity in a randomly selected multiracial group of urban adolescent schoolchildren in the Cape Metropole area of Cape Town. The information updates that provided by Jinabhai et $\mathrm{a}^{32}$ and Matsha et $\mathrm{al}^{36}$ and highlights the fact that in-depth studies are needed in the different regions of South Africa to improve an understanding of the weight to height ratio of specific groups of adolescents, based on demographics.

\section{Method}

\section{Ethics}

Approval for this study was provided by the Committee for Human Resources at Stellenbosch University and the Western Cape Department of Education. School permission and parental consent were obtained.

\section{Reference population}

School students were sampled from four educational districts, known as Education Management Development Centres (EMDCs), which together make up the greater Cape Town school population. The four EMDCs are Metropole North, South, East and Central. The EMDCs consist of 196 secondary schools, with 18925 multiracial high-school students in total.

\section{Sampling frame}

A complex cluster sampling procedure was followed whereby 36 students per school were selected from randomly selected schools in the four EMDCs. Students in grade 8-12 were eligible 


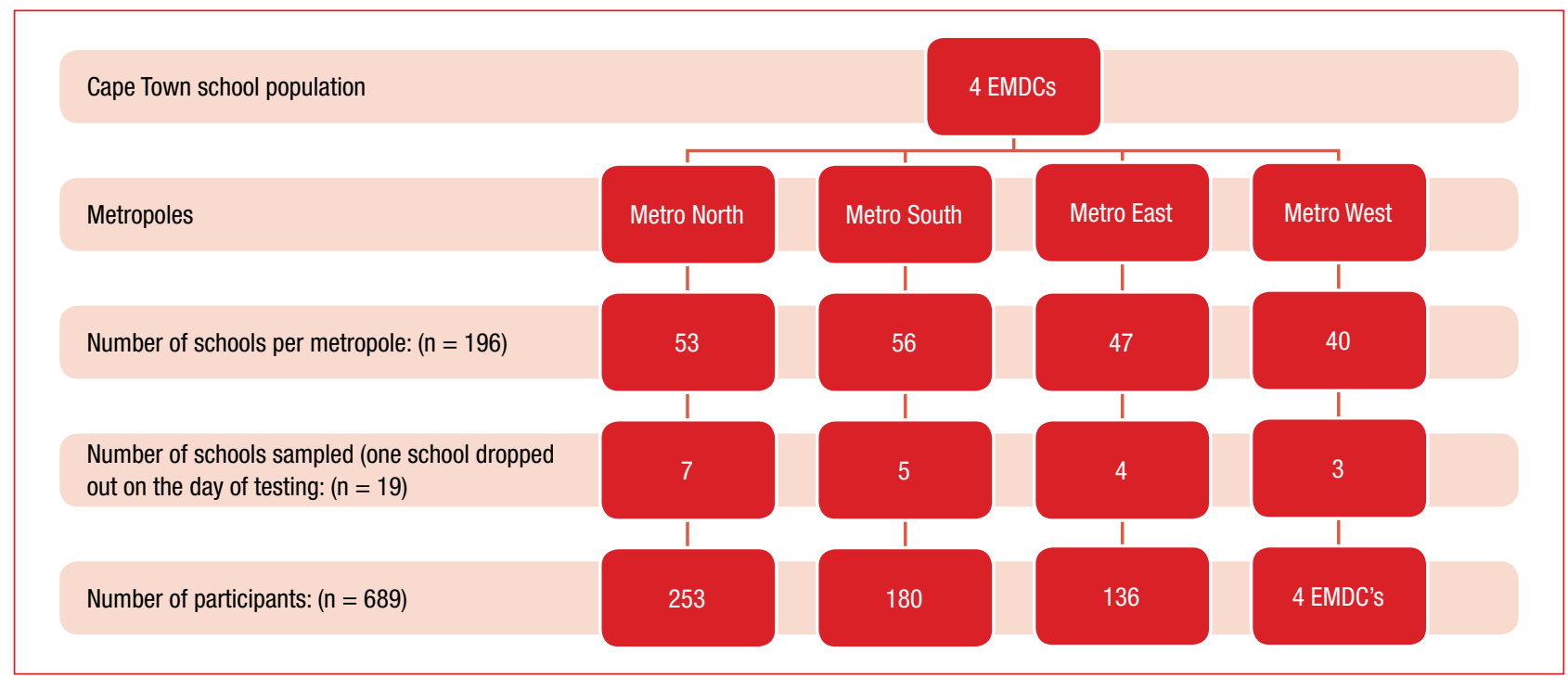

Figure 1: Sampling procedure to determine the number of participants needed per Education Management Development Centre

Table III: Number of study participants per age group

\begin{tabular}{|l|c|c|c|c|c|c|c|}
\hline Participants & $\mathbf{1 3}$ years & $\mathbf{1 4}$ years & $\mathbf{1 5}$ years & $\mathbf{1 6}$ years & $\mathbf{1 7}$ years & $\mathbf{1 8}$ years & Total \\
\hline Adolescent girls & $\mathbf{5 4}$ & $\mathbf{5 2}$ & $\mathbf{6 4}$ & $\mathbf{5 7}$ & $\mathbf{5 9}$ & $\mathbf{6 1}$ & 347 \\
\hline Adolescent boys & 49 & 57 & 63 & 59 & 56 & 58 & 342 \\
\hline Total (n) & 103 & 109 & 127 & 116 & 115 & 119 & 689 \\
\hline Total (\%) & 14.92 & 15.79 & 18.40 & 16.81 & 16.66 & 17.39 & 100 \\
\hline
\end{tabular}

for inclusion. The total number of schools selected in each EMDC was proportional to the size of the EMDC in the total Cape Town metropolitan population.

Twenty schools were consequently randomly cluster sampled from the school reference population. A sample of 720 students was sought from these schools.

Students in grade 8-12, aged 13-18 years who were enrolled in the randomly selected school, were eligible to take part in the study. No exclusion criteria were applied. Eligible students were invited to express their interest in participating in the study, and those who responded formed the student reference group. Three adolescent boys and three adolescent girls aged 13-18 years were then randomly sampled from this reference group from each of the randomly selected schools.

\section{Measurement process}

Three students were measured simultaneously by three research assistants using a standard protocol. Height was measured as the vertical distance from the floor to the top of the head. ${ }^{41-45}$ Weight was measured with an electronic scale, to the nearest milligram. A T-square was used to measure height, and a standard bathroom scale to measure body weight. Information on student age, gender and school class was also collected.

\section{Data handling and analysis}

Subjects were classified as overweight or obese according to the absolute age- and gender-specific cut-offs for BMl according to the International Obesity Task Force. ${ }^{2}$ Thinness was determined according to the international cut-off points for thinness according to gender and age. ${ }^{3}$

Data were analysed using SPSS ${ }^{\circledR}$ for Microsoft $^{\circledR}$ Windows $^{\circledR} 8$. Descriptive statistics were reported (mean, standard deviation and standard error of the mean) for height, weight and BMI per age and gender. The prevalence of underweight, overweight and obesity was reported in percentages, in age and gender categories. Comparisons were made between these data sets and the South African adolescent data sets, as well as international prevalence figures.

\section{Results}

Nineteen schools participated in the study. The total consenting sample comprised 689 students aged 13-18 years. Figure 1 illustrates the sampling procedure.

In total, 342 adolescent boys and 347 adolescent girls participated in the study. The percentage of students in the gender and age groups is described in Table III.

Table IV outlines the prevalence of underweight and overweight in the sample, according to age group. Almost $50 \%$ of the 13 -year-old schoolchildren were underweight. The 15 -year-old schoochildren had the highest prevalence of obesity. If the combined prevalence of overweight and obesity is taken into consideration, the highest prevalence was found in the 18-year-old schoolchildren (19.1\%).

Table V demonstrates that there were considerably more underweight adolescent boys than adolescent girls in the study (17.3\% boys to 
$9.9 \%$ girls), and double the frequency of overweight adolescent girls compared to adolescent boys ( $7.7 \%$ girls to $3.5 \%$ boys).

Table VI outlines the prevalence of underweight and overweight adolescents in the sample, according to gender and age group. The highest prevalence of underweight was found in the 14-year-

Table IV: Prevalence of underweight, overweight and obesity in school learners according to age

\begin{tabular}{|l|c|c|c|c|}
\hline Age (years) & $\begin{array}{c}\text { Underweight } \\
(\%)\end{array}$ & $\begin{array}{c}\text { Normal } \\
(\%)\end{array}$ & $\begin{array}{c}\text { Overweight } \\
(\%)\end{array}$ & $\begin{array}{c}\text { Obese } \\
(\%)\end{array}$ \\
\hline 13 & 48.1 & 6.7 & 5.8 & 5.8 \\
\hline 14 & 42.2 & 45 & 10.1 & 2.8 \\
\hline 15 & 26.2 & 57.1 & 8.7 & 7.9 \\
\hline 16 & 19 & 65.5 & 12.1 & 3.4 \\
\hline 17 & 17.4 & 65.2 & 15.7 & 1.7 \\
\hline 18 & 21 & 58.8 & 13.4 & 6.7 \\
\hline Total & 27.1 & 56.9 & 11.2 & 4.8 \\
\hline
\end{tabular}

Table V: Prevalence of underweight, overweight and obesity in school learners according to gender

\begin{tabular}{|l|c|c|c|c|}
\hline Gender & $\begin{array}{c}\text { Underweight } \\
(\%)\end{array}$ & $\begin{array}{c}\text { Normal } \\
(\%)\end{array}$ & $\begin{array}{c}\text { Overweight } \\
(\%)\end{array}$ & $\begin{array}{c}\text { Obese } \\
(\%)\end{array}$ \\
\hline $\begin{array}{l}\text { Adolescent } \\
\text { boys }\end{array}$ & 17.3 & 26.6 & 3.5 & 2.2 \\
\hline $\begin{array}{l}\text { Adolescent } \\
\text { girls }\end{array}$ & 9.9 & 30.3 & 7.7 & 2.6 \\
\hline Total & 27.1 & 56.9 & 11.2 & 4.8 \\
\hline
\end{tabular}

Table VI: Prevalence of underweight, overweight and obesity in school learners according to age and gender $(n=687)$

\begin{tabular}{|c|c|c|c|c|}
\hline School learners & $\begin{array}{c}\text { Underweight } \\
(\%)\end{array}$ & Normal (\%) & $\begin{array}{c}\text { Overweight } \\
(\%)\end{array}$ & Obese (\%) \\
\hline 13-year-old girls & 31.5 & 53.7 & 9.3 & 5.6 \\
\hline 13-year-old boys & 48 & 42 & 6 & 4 \\
\hline 14-year-old girls & 28 & 54 & 14 & 4 \\
\hline 14-year-old boys & 55.2 & 37.9 & 5.2 & 1.7 \\
\hline 15-year-old girls & 21.9 & 59.4 & 12.5 & 6.3 \\
\hline 15 -year-old boys & 30.2 & 55.6 & 3.2 & 11.1 \\
\hline 16-year-old girls & 12.3 & 66.7 & 15.8 & 5.3 \\
\hline 16-year-old boys & 25.9 & 62.1 & 10.3 & 1.7 \\
\hline 17-year-old girls & 11.9 & 64.4 & 22 & 1.7 \\
\hline 17-year-old boys & 23.6 & 67.3 & 9.1 & 0 \\
\hline 18-year-old girls & 15.8 & 56.1 & 19.3 & 8.8 \\
\hline 18-year-old boys & 29.6 & 59.3 & 7.4 & 3.7 \\
\hline
\end{tabular}

old boys (55.2\%) and the highest prevalence of overweight in the 17 -year-old girls (22\%). The highest prevalence of obesity was found in the 15 -year-old boys $(11.1 \%)$, who also demonstrated a relatively high prevalence of underweight (30.2\%).

Table VII provides information on the prevalence of underweight, overweight and obesity in school learners according to the socioeconomic status of the school. Quintile 1 refers to the poorest schools and quintile five to the most affluent schools. More than $50 \%$ of the school learners were within the normal ranges of weight.

\section{Discussion}

This study presents rare information on South African adolescents currently living in the Cape Metropole with regard to the existence of a double burden of malnutrition and underweight, and overweight or obesity. The study demonstrated that there was a higher prevalence of undernutrition in adolescent boys (specifically in 14-year-old boys) than in adolescent girls. This confirms the findings of other studies conducted on adolescents elsewhere in South Africa. ${ }^{32,38}$

However, our study reported on a substantial percentage of underweight adolescents $(27.1 \%)$ in the Cape Metropole area in South Africa. This value has almost tripled in the past 10 years since the Reddy et al ${ }^{38}$ study, and is nearly $10 \%$ more that of the findings reported by Jinabhai et al. ${ }^{32}$ This provides evidence of the importance of ongoing monitoring of the prevalence of underweight, overweight and obesity in South African adolescents, particularly as the genetic background of children changes, and the economics of the country stabilises. The data cited in this paper on the underweight, and overweight and obesity prevalence of adolescents in the Elgin Court region of Mpumalanga, and adolescents in the Cape Metropole region of the Western Cape, illustrate two very different scenarios. This might be because of differences in racial composition in these areas, and/or participants' access to food, and highlights the importance of having area-, or at least province-specific, data.

At national level, undernutrition (malnourishment), as a result of lowered economic productivity, is more likely to lead to poor educational outcomes, resulting in lower incomes, higher fertility rates and the potential for suboptimal care of the resultant children over time, thereby contributeing to the intergenerational transfer of poverty. ${ }^{13,46}$ However, it is notable that just over $50 \%$ of learners were within the normal range of weight in the school quintiles. This implies that half of the children in our sample had obtained an appropriate level of nutrition, and thus benefitted from positive

Table VII: Prevalence of underweight, overweight and obesity in school learners according to the socio-economic status of the school

\begin{tabular}{|l|c|c|c|c|c|c|}
\hline Quintile & Number of schools & $\begin{array}{c}\text { Number of students } \\
(\mathbf{n})\end{array}$ & $\begin{array}{c}\text { Underweight } \\
(\mathbf{\%})\end{array}$ & $\begin{array}{c}\text { Normal } \\
(\mathbf{\%})\end{array}$ & $\begin{array}{c}\text { Overweight } \\
(\mathbf{\%})\end{array}$ & $\begin{array}{c}\text { Obese } \\
(\mathbf{\%})\end{array}$ \\
\hline 1 & 1 & 52 & 23.1 & 57.7 & 15.4 & 3.8 \\
\hline 2 & 1 & 35 & 25.7 & 71.4 & 8.6 & 2.9 \\
\hline 3 & 3 & 96 & 24 & 56.3 & 14.6 & 5.2 \\
\hline 4 & 5 & 175 & 30.3 & 58.3 & 9.7 & 1.7 \\
\hline 5 & 9 & 329 & 27.1 & 55.6 & 10.6 & 6.7 \\
\hline
\end{tabular}


outcomes relating to good nutrition. The prevalence of children with normal weight compares to similar studies that were conducted in the Western Cape, but less so to the studies that incorporated a countrywide sample..$^{36,37}$

It is likely that in our study, the differential prevalence of undernutrition according to gender was owing to a delay in pubertal growth in the adolescent boys, compared to that in the adolescent girls. This occurs when undernutrition is prevalent in a community. ${ }^{47}$ Studies conducted on younger children indicate that disproportionate male undernutrition occurs in households with a low socio-economic status. The gender difference has no impact on households with a higher income. ${ }^{48}$ Further investigations into potential gender differences in malnutrition in adolescence are required.

Noteworthy levels of overweight and obesity in adolescent girls added to the substantial prevalence of undernutrition in adolescent boys in this study. Generally, adolescent overweight or obesity is associated with many health problems, including a heightened risk of psychosocial morbidity, asthma, orthopaedic difficulties, cardiovascular complications, and type 1 and type 2 diabetes. ${ }^{16}$ Furthermore, it is likely that overweight or obese adolescents become obese adults, and are therefore at increased risk of cardiovascular disease and other forms of morbidity, premature death, and impaired social, education and economic productivity. ${ }^{16,49}$ Overreliance on energy-dense processed foods, purchased because of insufficient local food production, may be a factor in the development of adolescent overweight and obesity in the Western Cape region of South Africa. In addition, physical inactivity and sedentary lifestyles are associated with adolescent overweight and obesity, ${ }^{50}$ with their attendant health issues. The potential role of human immunodeficiency virus (HIV) and acquired immune deficiency syndrome (AIDS) in the persistence of undernutrition in the study community must not be underestimated. The high prevalence of HIV/AIDS has an extensive effect on food security as it undermines the ability of households to provide for their basic needs. ${ }^{5}$

The higher reported prevalence of obesity in adolescent girls (than in adolescent boys) in our study is in keeping with many studies in other low- and middle-income countries, ${ }^{52}$ and in South Africa in particular. ${ }^{30,31}$ The South African Youth Risk Behaviour Survey documented the national prevalence of combined overweight and obesity of $21 \%$ in 13- to 19 -year-old learners in high school; $7 \%$ in adolescent boys and $25 \%$ in adolescent girls. ${ }^{37}$ Several factors may explain these gender differences. Biologically, energy needs differ in adolescent boys and girls, and also in relation to the rate of their growth. The timing of sexual maturation also varies, depending on gender. ${ }^{53}$ Behavioural factors are important in explaining sex differences too. Generally, boys are more physically active than girls, especially in adolescence. ${ }^{34,37}$ Concerns about body image, particularly in adolescent girls, may lead to problematic eating behaviour and the establishment of irregular meal patterns, which can result in increased weight gain. ${ }^{54}$ It is interesting to note that both underweight and obesity were observed in the schools with relatively higher quintiles. This was an unexpected finding, but may be reflective of the diverse backgrounds of children attending a specific school. However, it may also relate to preferential, abnormal eating habits which could lead to over- or underweight in high school learners. The reasons behind this finding should be explored in future studies. ${ }^{55}$ Differential problematic eating behaviour according to gender has previously been reported in South African youth..$^{55}$

This study did not collect data on food intake and physical activity patterns which may have provided information that could have explained our findings with regard to the prevalence of overweight and underweight in our sample population. The cross-sectional design of this study did not allow for a causal analysis of the mechanisms that contributed to weight outside of the normal range. However, based on the findings of our study, further targeted research should be undertaken to explore reasons for the continuing prevalence of the double burden of nutrition in Cape Metropole adolescents, and to investigate ways of addressing this.

\section{Conclusion}

Africa cannot afford a new generation of unhealthy adults. The continent has enough to contend with in respect to transmissible diseases, without additional lifestyle-based health burdens. Therefore, it is important that the broader community is educated on eating and exercising well, as a healthy lifestyle is essential in underpinning improved and sustainable population health.

\section{References}

1. World Health Organization. Controlling the global obesity epidemic. WHO [homepage on the Internet]. 2003. Available from: http://www.who.int/nut/obs.htm

2. Cole TJ, Bellizzi MC, Flegal KM, Dietz WH. Establishing a standard definition for child overweight and obesity worldwide: international survey. BMJ. 2000;320(7244):1240-1243.

3. Cole TJ. Weight-stature indices to measure underweight, overweight, and obesity. Anthropometric assessment of nutritional status. New York: Wiley-Liss; 1991.

4. Bua J, Olsen LW, Sørensen TIA. Secular trends in childhood obesity in Denmark during 50 years in relation to economic growth. Obesity. 2007;15(4):977-985.

5. World Health Organization. The world health report 2002: reducing risks, promoting healthy life. Geneva: WHO; 2002.

6. Singhal N, Misra A, Shah P, et al. Secular trends in obesity, regional adiposity and metabolic parameters among Asian Indian adolescents in north India: a comparative data analysis of two selective samples 5 years apart $(2003,2008)$. Ann Nutr Metab. 2010;56(3):176-181.

7. Lazarus $\mathrm{R}$, Wake $\mathrm{M}$, Hesketh $\mathrm{K}$, Waters $\mathrm{E}$. Change in body mass index in Australian primary school children, 1985-1997. Int J Obes Relat Metab Disord. 2000;24(6):679-684.

8. Gonzalez-Suarez C, Worley A, Grimmer-Somers K, Dones V. School-based interventions on childhood obesity: a meta-analysis. Am J Prev Med. 2009;37(5):418-427.

9. De Klerk M, Drimie S, Aliber M, et al. Food security in South Africa: key policy issues for the medium term. Human Sciences Research Council Integrated Rural and Regional Development; 2004

10. Popkin BM. The nutrition transition and obesity in the developing world. J Nutr. 2001;131(3):871S-873S.

11. Motlagh ME, Kelishadi R, Amirkhani MA, et al. Double burden of nutritional disorders in young Iranian children: findings of a nationwide screening survey. Public Health Nutr.2010;14(4): 605-610.

12. Dietz W, Robinson T. Use of the body mass index (BMI) as a measure of overweight in children and adolescents. J Pediatr. 1998;132(2):191-193.

13. Victora CG, Adair L, Fall $C$, et al. Maternal and child undernutrition: consequences for adult health and human capital. Lancet. 2008;371(9609):340-357.

14. Lanigan J, Singhal A. Early nutrition and long-term health: a practical approach. Proc Nutr Soc. 2009;68(4):422-429.

15. Monyeki KD, Kemper HCG, Makgae PJ. The association of fat patterning with blood pressure in rural South African children: The Ellisras Longitudinal Growth and Health Study. Int J Epidemiol. 2006;35(1):114-120. 
16. Reilly J, Methven E, McDowell Z, et al. Health consequences of obesity. Arch Dis Child. 2003;88(9):748-752

17. Guo SS, Chumlea WC. Tracking of body mass index in children in relation to overweight in adulthood. Am J Clin Nutr. 1999;70(1):145S-148S.

18. Cole TJ, Freeman JV, Preece MA. Body mass index reference curves for the UK, 1990 Arch Dis Child. 1995;73(1):25-29.

19. Barlow SE, Dietz WH. Obesity evaluation and treatment: expert committee recommendations. Pediatrics.1998;102(3):e29-e29.

20. Bellizzi MC, Dietz WH. Workshop on childhood obesity: summary of the discussion. Am J Clin Nutr.1999;70(1):173S-175S.

21. Monteiro CA, Benicio M, lunes $R$, et al. Nutritional status of Brazilian children: trends from 1975 to 1989. Bull World Health Organ.1992;70(5):657-656.

22. Power C, Lake J, Cole T. Measurement and long-term health risks of child and adolescent fatness. Int J Obes Relat Metab Disord. 1997;21(7):507-526.

23. World Health Organization. Physical status: the use and interpretation of anthropometry Geneva: WHO; 1995.

24. Abrantes MM, Lamounier JA, Colosimo EA. Comparison of body mass index values proposed by Cole et al (2000) and Must et al (1991) for identifying obese children with weight-for-height index recommended by the World Health Organization. Public Health Nutr. 2003;6(3):307-312.

25. Rolland-Cachera MF, Sempe M, Guilloud-Bataille M, et al. Adiposity indices in children. Am J Clin Nutr. 1982;36(1):178-184.

26. Önera N, Vatansevera Ü, Saria A, et al. Prevalence of underweight, overweight and obesity in Turkish adolescents. Swiss Med Wkly. 2004;134(35-36):529-533.

27. Lissau I, Overpeck MD, Ruan W, et al. Body mass index and overweight in adolescents in 13 European countries, Israel, and the United States. Arch Pediatr Adolesc Med. 2004;158(1):27-33.

28. Janssen I, Katzmarzyk P, Boyce W, et al. Comparison of overweight and obesity prevalence in school-aged youth from 34 countries and their relationships with physical activity and dietary patterns. Obes Rev. 2005;6(2):123-132.

29. Wang Y, Monteiro C, Popkin BM. Trends of obesity and underweight in older children and adolescents in the United States, Brazil, China and Russia. Am J Clin Nutr. 2002;75(6):971-977

30. Amstrong MEG, Lambert MI, Sharwood KA, Lambert EV. Obesity and overweight in South African primary school children: The Health of the Nation Study. S Afr Med J. 2006;96(5):439-444

31. Department of Health, Medical Research Council, OrcMacro. South African Demographic and Health Survey document. 2003;156-162.

32. Jinabhai CC, Reddy P, Taylor M, et al. Sex differences in under and over nutrition among school-going black teenagers in South Africa: an uneven nutrition trajectory. Trop Med Intl Health. 2007;12(8):944-952.

33. Kimani-Murage E, Kahn K, Pettifor J, et al. The prevalence of stunting, overweight and obesity, and metabolic disease risk in rural South African children. BMC Public Health. 2010;10:158.

34. Kruger R, Kruger HS, Macintyre UE. The determinants of overweight and obesity among 10- to 15-year-old schoolchildren in the North West Province, South Africa: The THUSA BANA (Transition and Health during Urbanisation of South Africans; BANA, children) study. Public Health Nutrition. 2006;9(3):351-358.

35. Makgae PJ, Monyeki KD, Brits SJ, et al. Somatotype and cardiovascular functions of rural
South African children aged 6 to 13 years: Elisras Longitudinal Growth and Health study. Annal Hum Biol. 2007;34(2):240-251.

36. Matsha $T$, Hassen $S$, Bhata A, et al. Metabolic syndrome in 10-16 year old learners from the Western Cape, South Africa: comparison of the NCEP ATP III and IDF criteria. Atherosclerosis. 2009;205(2):363-366.

37. Naude D, Kruger HS, Pienaar AE, Mamabolo RL. Body fat, body mass index in black South African adolescants after a physical activity intervention program: Play Study. African Journal for Physical, Health Education, Recreation and Dance. 2008;14(4):440-455.

38. Reddy S, Panday S, Swart D, et al. Umthenthe Uhlaba Usamila: The South African Youth Risk Assessment Survey, 2002. Cape Town: Medical Research Council; 2003.

39. Steyn N, Nel J, Nantel G, et al. Food variety and dietary diversity scores in children: are they good indicators of dietary adequacy? Public Health Nutr. 2006;9(5):644-650.

40. Morgan M, Fairchild R, Phillips A, et al. A content analysis of children's television advertising: focus on food and oral health. Public Health Nutr. 2008;12(6):748-755.

41. Gouvali M, Boudolos K. Match between school furniture dimensions and children's anthropometry. Appl Ergon. 2006;37(6):765-773

42. Panagiotopoulou G, Christoulas K, Papanckolaou A, Mandroukas K. Classroom furniture dimensions and anthropometric measures in primary school. Appl Ergon. 2004;35(2):121-128.

43. Mououdi M, Choobineh A. Static anthropometric characteristics of students age range six-11 in Mazandaran province/lran and school furniture design based on ergonomics principles. Appl Ergon. 1997;28(2):145-147.

44. Milanese S, Grimmer K. School furniture and the user population: an anthropometric perspective. Ergonomics. 2004;47(4):416-426.

45. Ray G, Ghosh S, Atreya V. An anthropometric survey of Indian schoolchildren aged 3-5 years. Appl Ergon. 1995;26(1):67-72.

46. World Bank. Repositioning nutrition as central to development: a strategy for large-scale action. Washington: World Bank; 2006.

47. Sedlmeyer IL, Palmert MR. Delayed puberty: analysis of a large case series from an academic center. J Clin Endocrinol Metab. 2002;87(4):1613-1620.

48. Wamani H, Tylleskär T, Åstrøm AN, et al. Mothers' education but not fathers' education, household assets or land ownership is the best predictor of child health inequalities in rural Uganda. Int J Equity Health. 2004;3(1):9.

49. Lanigan J, Singhal A. Early nutrition and long-term health: a practical approach. Proc Nutr Soc. 2009;68(4):422-429.

50. Lajous M, Chavarro J, Peterson KE, et al. Screen time and adiposity in adolescents in Mexico. Public Health Nutr. 2009;12(10):1938-1945.

51. De Waal A, Whiteside A. New variant famine: AIDS and food crisis in southern Africa. Lancet. 2003;362(9391):1234-1237.

52. Neutzling M, Taddei J, Rodrigues E, Sigulem D. Overweight and obesity in Brazilian adolescents. Int J Obes. 2000;24(7):869-874

53. Wisniewski $A B$, Chernausek SD. Gender in childhood obesity: family environment, hormones, and genes. Gend Med. 2009;6 Suppl 1:76-85.

54. Neumark-Sztainer D, Paxton SJ, Hannan PJ, et al. Does body satisfaction matter? Five-year longitudinal associations between body satisfaction and health behaviors in adolescent females and males. J Adolesc Health. 2006;39(2):244-251.

55. Le Grange D, Telch CF, Tibbs J. Eating attitudes and behaviors in 1,435 South African Caucasian and non-Caucasian college students. Am J Psychiatry. 1998:155(2):250-254. 